\title{
The Relationship between Education, Employment and Income
}

\author{
LENKA PALAŠČÁKOVÁ \\ Department of Security and Defense, Armed Forces Academy \\ of General Milan Rastislav Štefánik \\ Daniela PalašČÁKovÁ \\ Department of Economics, Faculty of Economics, \\ Technical University of Košice
}

\begin{abstract}
The issue of interrelationships between education, employment and the level of income evaluation is of cross-cutting nature, where the economic, social, political and legal levels are intertwined. Its broader context predicts its thematic coverage. The article presents preliminary results of the mutual relationship between acquired skills and the level of education achieved and the ability of an individual to become involved in the labour market. The aim of the article is to determine, using statistical and analytical methods, the correlation between the employment rate and the level of education attained in EU countries and within the territory of the Slovak Republic. On the basis of the initial
\end{abstract}


analysis our aim is to answer the question if university-educated people achieve higher incomes than secondary-educated people and eventually, to try to propose solutions and measures that are necessary for increasing the level and value of human capital, especially in the Slovak Republic.

Keywords: global value chains, human resources, capital, wage, income, education, employment JEL Classification Codes: E24, I29, J24

\section{Introduction}

Economic growth is necessary for the development of every country and society. There are many factors influencing economic growth. Among all social or economic aspects, it is necessary to provide an increase in human capital. Human capital will be of higher quality if investments are capitalised properly into this type of capital and if the state provides a high-quality education system available to everybody. Education is the main element of human capital (Heckman, 1998). The countries within their interest of Global Value Chains (hereinafter refered to as GVC) must invest in education and professional preparation, use the skills more effectively, coordinate the policies more in the field of competencies - from the policy of education and migration policy to legal regulations for the protection of employment - and coordinate these policies with industrial and commercial policy. The growth of human capital positively influences other factors of growth, stimulates technological progress (Galor \&Tsiddon, 1997), indirectly supports the growth of physical capital (Dobeš, 2000, 2017) and positively influences employment (Kačírková, 1998).

The development and education of employees are visible in the growth of profits caused by higher work productivity. Thus, we talk about the increase in profits from human capital visible even in the growth of income possibilities of an employee (Lisý, 2007). Human capital is related to the efficiency of the economy through incomes. Due to income, an individual is able to get some benefits from his/her own human capital. Many authors consider income as a source for their calculations of the economic return of the investments in human capital and the entire society as well. Dobeš (2000, p. 789) claims that: "if we accept the approximation that the amount of income reflects the amount of work productivity, we can infer the differentiation of income according to the level of education reflects even the differentiation of a direct added value for society by education."

Regarding what we have mentioned above, there is an important question to be asked; whether postgraduates, whom we considered being the bearers of a higher 
level of human capital, earn more on average than undergraduates. Theoretically, the bearers of a higher level of human capital should be more productive. The basic goal of this paper is to find out the mutual relationship between the rate of employment and the acquired level of education in EU countries, especially the Slovak Republic, through the analytical and statistical methods. Based on the primary analysis, we want to respond to the questions whether there is a slightly increased rate of employment of Slovak population altogether with the increasing level of acquired education, and whether postgraduates are worthy of higher incomes than undergraduates.

\section{Analysis of human capital in succeeding in the labour market}

The understanding of human capital as a production factor in economic understanding, within the context of prosperity and interrelatedness of human competencies, with the possibility of achieving higher assessment, was proclaimed by Adam Smith in his work The Wealth of Nations in 1776, later cited by Armstrong in his publication: "the achieved wealth of nations comes from the achieved human competencies - their education, knowledge, experience, and health" (Armstrong, 2007, Armstrong \& Taylor, 2015, p. 928). In 1964, Becker, in his book Human Capital claimed the significance of human capital in particular fields of economic practice through which he significantly developed the incorporation of this term into the economic practice (Becker, 1993). He differentiates between the types of activities bringing us utility immediately and the ones of which we can expect the utility output in the future. We call the process through which we acquire utilities in the future, the investment into human capital when we subsume school education, workshops and providing for healthcare.

Currently, the problem of investment into human capital and the consequences of these investments is broadly researched, however not complete. With time, a significant amount of empirical studies have been produced in order to improve the methods of estimation of the benefits from the investments at the level of private and social profits. The presumption of higher return from investing in human capital is, for instance, when an undergraduate employee has not only a higher salary but he/she can even avoid the status of being unemployed for a long time. On the other hand, for instance, investments into primary education bring the highest profits in the developing countries.

Most theoretical models consider human capital as the asset necessary for economic decision-making of individuals. We cannot measure its profit directly as a non-marketable asset, therefore, its approximation is necessary (Lee, Ihm and Ryu, 2017). The analysis of human capital deals with non-accumulated competence acquired 
and developed by formal and informal education at school, home and training, work experience and mobility within the labour market (Mincer, 1958, 1994).

According to Onkelinx, Manolova, and Edelman (2016), investment in human capital leads to higher productivity in the following period. The employees having a high rate of human capital help in implementing new technologies or software in a production process rather than being resistant to change. They are generally more flexible in adjusting to changes (Danquah \& Amankwah-Amoah, 2004). However, the difference is not only within the production process but even at higher levels of management where flexibility or dynamics is a key part of decision-making processes leading to societal growth (Bielik, 2007).

The results of the study led by Barro (1996) showed a significant positive influence in the number of years spent in secondary and tertiary education of men aging from 25 upwards on economic growth. The influence of an additional year spent in higher education was estimated for $1.2 \%$ annually. Another study shows that an additional year in education results in the GDP increase of $6 \%$ per inhabitant. The study was conducted out of the data of OECD countries from 1971 to 1998 (Bassanini \& Scarpettea, 2001). The model revealed a statistically significant positive relationship between GDP per inhabitant and two explanatory elements: 1. Innovative capacity of human capital (measured by the number of patents) and 2. Employees' qualification (secondary education) that was in accordance with the theory. Thus, the more patents, the higher the growth as well as the higher the number of at least secondary educated population, the higher economic growth (Pelinescu, 2015).

The same result, regarding the question of whether human capital is the determinant of growth, was obtained by Hanushek and Woessmann (2012) through a totally different method. They criticised the measuring of human capital through the years spent in the education system because, according to them, it does not reflect the differences in education systems. They believe: "The analysis measuring the human capital through the average number of years spent in an education system results from the assumption that every education system brings the same knowledge and experience growth" (Hanushek \& Woessmann, 2012, pp. 73-109 (p. 77), Hanushek 2012). Because of this deficiency, they decided to use the measurement based on cognitive competencies. The result of their study was that the differences in cognitive competencies lead to significant changes in economic growth. The implication of their research is that the change in the education approach (if it is effective in the cognitive competencies growth) can be an important source supporting economic growth.

As we have already stated, the conditions of the economic development of a particular country cause the population with higher education to be more productive, therefore, getting higher incomes in comparison to a less educated population. As 
there are higher incomes, consequently, savings grow, too, as well as consumption grows slowly. The reason is that the limiting gradient towards consumption is lower than the limiting gradient towards savings (Lisý, 2007). Beside the fact that growing income caused by higher education increases the amount of consumption, even its structure changes (Michael, 1975).

The income growth achieved in other ways than improved education causes a higher growth in the consumption services than investment in real-estate. The fact makes the base for a comparison with the situation in case income has grown by acquiring human capital (Mazouch \& Fischer, 2011). In this case, the amount of consumption services increases five times less than in the previous case and the amount of real-estate acquisition even decreases slightly. Data has been tested on fifteen consumption services and real-estate acquisitions. For instance, the volume of tobacco product sales, in the case of an income growth without additional education, has been influenced positively and in the case of income growth caused by an additional year of education, has been influenced negatively (Michael, 1975). It means the growth of income changes the amount of the consumption of services and real-estate acquisitions, but their rate inclines towards services. However, education changes the overall structure of consumption (Blundell, 1999).

\section{Methodology and the methods used}

For the purpose of detailed research and processing the gathered data, we used both statistical methods as well as basic scientific methods. We used a correlation analysis for analysing mutual relationships between particular researched parameters. The result of the correlation analysis is correlation coefficient $r$ which can reach the values at intervals from -1 to +1 . It stands that if $r=0$, then there is no linear dependency between the variables. The coefficient of correlation expresses the power of the relationship between the variables. The numeric value of $r$ expresses the relationship strength between the variables and the sign determines the direction of the relationship (direct, indirect). We indicate the Pearson correlation coefficient as the correlation coefficient more specific and the most frequent. However, we worked with a simple correlation coefficient $r$, because the condition for using the Pearson coefficient is to have a linear dependency between two variables $\mathrm{X}$ and $\mathrm{Y}$. According to Hudec (2007), the correlation analysis compared to regression analysis does not express the cause-effect relationship between variables $\mathrm{X}$ and $\mathrm{Y}$. Variable $\mathrm{Y}$ does not depend on variable $\mathrm{X}$, but two occasional variables $\mathrm{X}$ and $\mathrm{Y}$ mutually change.

We focused on the research of the relationship between the employment and the acquired level of education as well as between the amount of gross income and the 
acquired level of education within Slovakia. We used the following formula in order to calculate the values of correlation coefficient $r$ (Hudec, 2007):

$$
r_{x y}=\frac{S_{x y}}{\sqrt{S_{x}^{2} S_{y}^{2}}},
$$

where: $S_{x y}=\sum_{i=1}^{n}\left(X_{i}-\bar{X}\right)\left(Y_{i}-\bar{Y}\right), S_{x}^{2}=\sum_{i=1}^{n}\left(X_{i}-\bar{X}\right)^{2}$ a $S_{y}^{2}=\sum_{i=1}^{n}\left(Y_{i}-\bar{Y}\right)^{2}$.

Features of correlation coefficient $r$ :

1. For $\mathrm{r} \in\langle-1 ; 1\rangle$; if:

$\mathrm{r}=\mathrm{O} \rightarrow \mathrm{X}$ and $\mathrm{Y}$ are not linearly dependent;

$\mathrm{r}>0 \rightarrow$ the assumed linear dependence between $\mathrm{X}$ and $\mathrm{Y}$ is straight;

$\mathrm{r}<0 \rightarrow$ the assumed linear dependence between $\mathrm{X}$ and $\mathrm{Y}$ is indirect;

$\mathrm{r}=+1 \rightarrow$ there is a full linear relationship between $\mathrm{X}$ and $\mathrm{Y}$;

$\mathrm{r}=-1 \rightarrow$ there is a complete indirect linear dependency between $\mathrm{X}$ and $\mathrm{Y}$.

2. We say about correlation between variables if:

$|r| \leq 0,3 \rightarrow$ is not shown;

$0.3<|\mathrm{r}|, 50.5 \rightarrow$ is moderate;

$0.5<|\mathrm{r}|, 70.7 \rightarrow$ is high;

$0.7<|\mathrm{r}|, 90.9 \rightarrow$ is significant;

$|\mathrm{r}|>0.9 \rightarrow$ is very tight.

We calculated the value of the correlation coefficient through the Correl function within the table processor of Microsoft Excel. Consequently, based on the calculated value, we could determine the strength of the mutual dependency between the researched parameters. The source of our research was data provided by Eurostat and the Statistical Office of the Slovak Republic in the period from 2007 to 2016. We did not count 2017 in our analysis because data had not been published yet at the time of preparing this paper.

\section{Results and discussion}

We analyse the mutual relationship between the employment rate and the acquired level of education of the population of 27 member EU countries aged between 15 and 64 in this subchapter. Slovakia is one of the researched countries. Data shown in Figure 1 is related to 2016 and represents the rate of employment within all the fields of the national economy. 
Figure 1. Employment rate of selected EU countries according to education, age 15-64, 2016 (in \%)

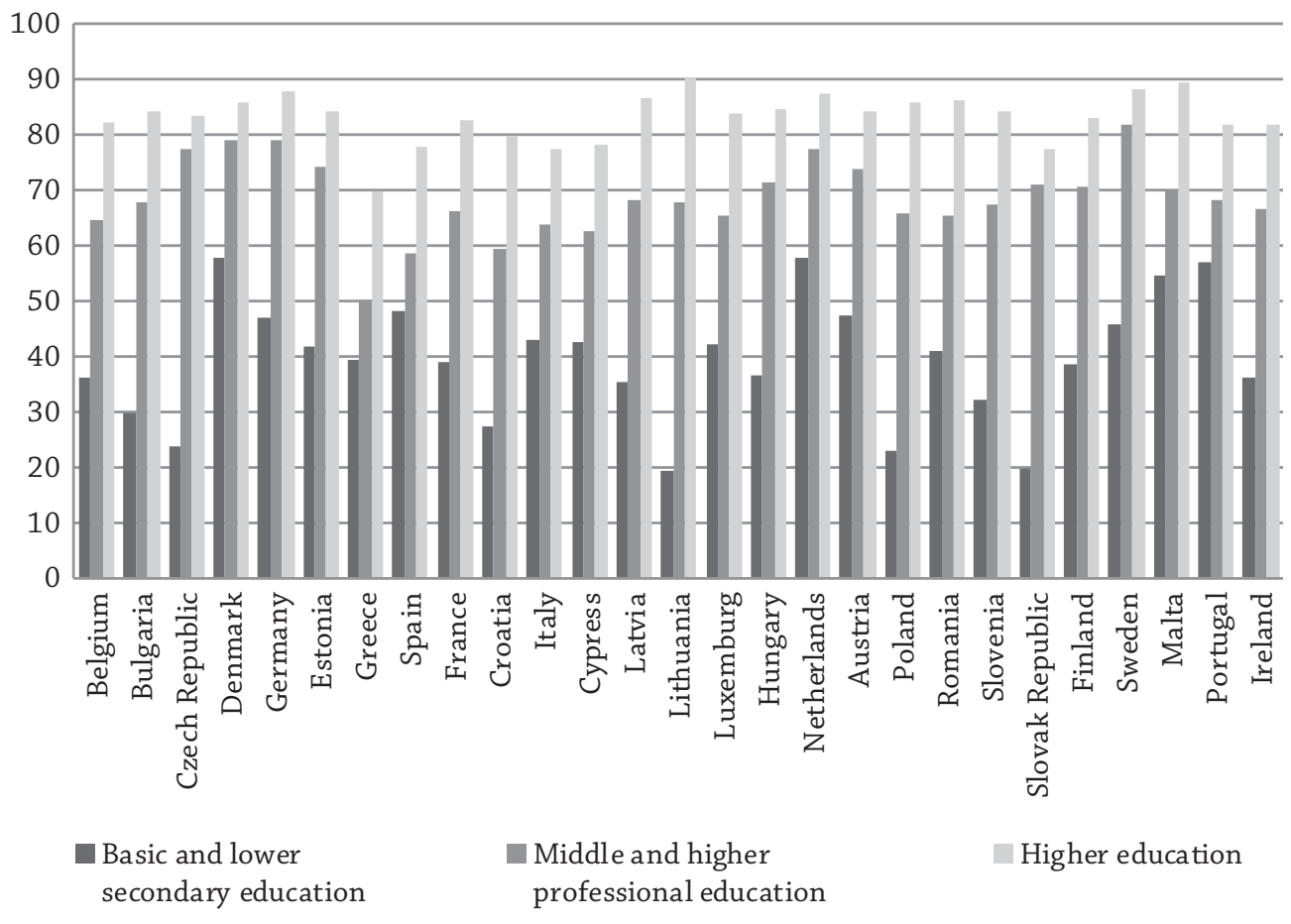

Source: own elaboration based on Eurostat data.

Based on the data shown in Figure 1, we can infer a relationship between the growing acquired education level and the growing percentage rate of population employment of all the researched EU countries with no exceptions. In the following year, 2016, the lowest rate of employment within the population of the primary and lower secondary education was acquired in the countries such as Lithuania, the Czech Republic, Poland, Croatia, as well as Slovakia, which are mostly Central European countries. Overall, the rate of employment of the population with primary and lower secondary education fluctuated from $19 \%$ to $57 \%$. On the other hand, the highest rate of employment was achieved by the population of postgraduates in Germany, the Netherlands, Malta, Sweden as well as Lithuania. We can presuppose the postgraduate population faces fewer problems with finding employment in comparison to other EU member countries. Generally speaking, it can be observed that in almost every analysed country and at every education level in 2016 there was a slight increase in the employment level. We evaluate this tendency very positively. The least employed graduates were in Greece, where the employment rate reached the level of $69.9 \%$. Overall, the employment rate of graduates fluctuates between $70 \%$ and $90 \%$ 
on average. Denmark, Germany, Luxemburg, the Netherlands, and Sweden belong to the countries reporting one of the lowest employment rates at all the levels. They are the countries of Northern and Western Europe.

\section{The results of the correlation between employment and the achieved level of education in Slovakia}

The number of working people is presented in the table below (Table 1), expressed by the achieved education level in 2007-2016. Through the statistics results we want to emphasize the fact the there is an increasing tendency to employ the population with higher education in Slovakia.

Table 1. Employees according to the acquired education level (population in thousands) in 2007-2016

\begin{tabular}{|c|c|c|c|c|c|}
\hline \multirow{2}{*}{ Year } & \multicolumn{5}{|c|}{ Achieved education } \\
\cline { 4 - 6 } & \multirow{2}{*}{ Primary } & \multirow{2}{*}{$\begin{array}{c}\text { Secondary full } \\
\text { vocational }\end{array}$} & primary & secondary & tertiary \\
\cline { 4 - 6 } & & 822.3 & 20.2 & 341.8 & 5.6 \\
\hline 2007 & 105.9 & 857.4 & 24.7 & 356.1 & 6.6 \\
\hline 2008 & 109.9 & 842.4 & 36.4 & 362.8 & 8.2 \\
\hline 2009 & 92.8 & 828.1 & 43.9 & 398.2 & 7.7 \\
\hline 2010 & 91.4 & 795.8 & 53.1 & 395.8 & 10.8 \\
\hline 2011 & 90.7 & 784.1 & 61.5 & 393.1 & 10.9 \\
\hline 2012 & 87.8 & 829.4 & 63.2 & 417.7 & 9.9 \\
\hline 2013 & 91.5 & 809.7 & 80.4 & 431.0 & 15.0 \\
\hline 2014 & 85.9 & 831.6 & 74.3 & 460.1 & 19.1 \\
\hline 2015 & 97.4 & 831.9 & 76.8 & 464.3 & 20.2 \\
\hline 2016 & 95.3 & & & & \\
\hline
\end{tabular}

Source: own elaboration based on data of the Statistical Office of the Slovak Republic.

As we can see in Table 1, the number of the employed population of tertiary postgraduates increased by 3.6 times in 2007-2016. There is the same upward tendency of employing the population of secondary postgraduates. However, the highest growth is recorded in employing the population of primary postgraduates, the number increased from 20,200 to 76,800 from 2007 to 2016. On the contrary, there is a downward tendency of employing the population with lower education. The number of employees achieving primary education only decreased by 10,600 during the observed period. At the same time, the highest number was reached by 
the population with the full secondary vocational education within the research period. On the other hand, the lowest number was reached by the population with tertiary postgraduate education. This group of employees acquires one of the highest values of the average monthly income in the long term.

Based on the results in Table 1, we performed the correlation analysis of the mutual relationship between the employment rate and the acquired education level within the conditions of the Slovak Republic. In order to simplify the calculation of the value of correlation coefficient $r$, we assigned different rates scaling from 1 to 5 to particular achieved education levels. The lowest rate we assigned to primary education and the highest one to the tertiary postgraduates. We set the value of the correlation coefficient through the Correl function within the table processor of Microsoft Excel. The results of the performed correlation analysis are listed in Table 2 below. As we can see, the value of correlation coefficient $r$ is 0.823 . The coefficient value means there is a significant correlation between the employment rate and the acquired education level of the population of Slovakia because the following condition was met: $0.7<|r=0.823|<0.9$. We can also claim there is a direct linear dependency between the researched variables because the following conditions were met: $\mathrm{r}=0.823>0$.

Table 2. Correlation between the rate of employment and the achieved education level in Slovakia in 2007-2016

\begin{tabular}{|l|c|c|}
\hline \multicolumn{1}{|c|}{ Achieved education } & Education rate & $\begin{array}{c}\text { Average rate of employment } \\
\text { (in \%) }\end{array}$ \\
\hline Primary & 1 & 57.95 \\
\hline Secondary full vocational & 2 & 91.15 \\
\hline Postgraduate primary & 3 & 92.09 \\
\hline Postgraduate secondary & 4 & 94.72 \\
\hline Postgraduate tertiary & 5 & 96.59 \\
\hline \multicolumn{2}{|c|}{} \\
\hline
\end{tabular}

Source: own elaboration based on data of the Statistical Office of the Slovak Republic.

In Table 2 we can see that the achieved education level slightly increases together with the rate of employment of the population of Slovakia. The lowest average rate of employment of $57.95 \%$ was reached in $2007-2016$ by employees with primary education. On the contrary, the highest average rate of employment of $96.59 \%$ was reached by employees with tertiary postgraduate education. Thus, we can state the higher level of education an individual can achieve, the higher his/her chance to find a job. 


\section{The results of the correlation between the gross income rate and the achieved education level in Slovakia}

In Table 3 we list the average gross monthly income expressed in the context of the achieved education in 2008-2016. This table demonstrates the fact that the average amount of gross monthly income depends on the achieved education. There is an upward tendency in the presented income altogether with the achieved education level.

Table 3. The structure of the average gross monthly income of an employee by the achieved education in 2008-2016

\begin{tabular}{|c|c|c|c|c|c|}
\hline \multirow{2}{*}{ Year } & \multicolumn{5}{|c|}{ Achieved education/Average gross monthly income (in $€$ ) } \\
\cline { 2 - 6 } & \multirow{2}{*}{ Primary } & \multirow{2}{*}{$\begin{array}{c}\text { Secondary full } \\
\text { vocational }\end{array}$} & Primary & Secondary & Tertiary \\
\cline { 4 - 6 } & & 691.69 & 826.86 & 1171.11 & 1233.39 \\
\hline 2007 & 461.53 & 758.68 & 900.05 & 1205.11 & 1276.74 \\
\hline 2008 & 493.03 & 764.00 & 928.67 & 1255.72 & 1305.76 \\
\hline 2009 & 501.64 & 788.00 & 937.00 & 1259.00 & 1304.00 \\
\hline 2010 & 515.00 & 814.00 & 930.00 & 1278.00 & 1307.00 \\
\hline 2011 & 536.00 & 841.00 & 951.00 & 1299.00 & 1331.00 \\
\hline 2012 & 559.00 & 865.00 & 969.00 & 1331.00 & 1355.00 \\
\hline 2013 & 587.00 & 909.00 & 1021.00 & 1397.00 & 1390.00 \\
\hline 2014 & 607.00 & 939.00 & 1058.00 & 1448.00 & 1444.00 \\
\hline 2015 & 673.00 & 951.00 & 1072.00 & 1462.00 & 1458.00 \\
\hline 2016 & 640.00 & & & & \\
\hline
\end{tabular}

Source: own elaboration based on data of the Statistical Office of the Slovak Republic.

Out of all compared categories, the greatest increase is evident in the average monthly income of employees with postgraduate secondary education. From 2014 we can observe the average gross monthly income to be slightly higher in the case of an employee achieving secondary postgraduate education than the one achieving tertiary postgraduate education. As the statistics data shows, the average gross monthly income of an employee with primary education was $818 €$ lower in 2016 , thus 2.3 times lower than in the case of an employee with tertiary postgraduate education. An employee with full secondary vocational education earned 1.4 times more than an employee with primary education, but 1.6 times less than an employee who achieved the secondary education level. Referring to the stated facts, we want to emphasize that the development of human capital leads to better financial assessment in the 
form of higher income in the long term. During the period between 2007-2016, the average monthly income of employees with primary education increased by $178.47 €$. The average monthly income of employees who achieved secondary postgraduate education level increased by $290.89 €$ in the same period of time. These facts show the average monthly income of employees with lower qualifications increases at a slower rate than the income of employees with the postgraduate education level.

Table 3 convincingly presents that the level of achieved education as a certain rate of human capital positively influences even the income amount. Higher incomes represent profit not only to an individual himself/herself but even for the entire national economy in the form of higher income taxes.

In Table 4, we present the results of the performed correlation analysis. In order to simplify the calculation of the value of the correlation coefficient $r$, we assigned the rates in a scale from 1 to 5 for each achieved education level. We assigned the lowest rate to primary education and the highest one to tertiary postgraduate education. Consequently, we calculated the value of the correlation coefficient using the Correl function within the table processor of Microsoft Excel.

Table 4. Correlation between the amount of the gross monthly income and the achieved education level in Slovakia in 2007-2016

\begin{tabular}{|l|c|c|}
\hline \multicolumn{1}{|c|}{ Achieved education } & Education rate & $\begin{array}{c}\text { Average amount of gross } \\
\text { monthly income (in } € \text { ) }\end{array}$ \\
\hline Primary & 1 & 553.7 \\
\hline Full secondary vocational & 2 & 832.1 \\
\hline Postgraduate primary & 3 & 959.4 \\
\hline Postgraduate secondary & 4 & 1310.6 \\
\hline Postgraduate tertiary & 5 & 1340.5 \\
\hline \multicolumn{2}{|c|}{ Value of correlation coefficient: 0.969 } \\
\hline
\end{tabular}

Source: own elaboration based on data of the Statistical Office of the Slovak Republic.

In Table 4 we can see that the average level of the gross monthly income of the population of the Slovak Republic increases with the achieved education level. The lowest average monthly income of 553.70 $€$ in the years 2007-2016 was reached by employees with primary education. On the other hand, the highest average monthly income of $1340.50 €$ was achieved by employees with tertiary education in the same period. As a result, there is a clear difference in income assessment among the presented groups of employees.

The value of correlation coefficient $r$ is 0.969 , meaning there is a very tight correlation between the average level of the gross monthly income and the achieved 
education level among the population of Slovakia because the following condition is met: $r=0.969>0.9$. We can also claim there is a direct linear dependence between the researched variables as the following condition is met: $r=0.969>0$. This dependence represents almost the entire direct linear dependence because coefficient value $r$ equals almost 1 .

\section{Conclusion}

People of Slovakia consider their education as an entrance ticket to the labour market. Based on the conducted analysis, we can conclude there is a very strong dependency between the achieved education level of an individual and his/her competence to find employment in the labour market. Similarly, the higher the education level an individual can achieve, the higher the chance to find financially well-assessed employment. This fact works not only for the Slovak labour market but even for the labour markets of other EU member countries (Kucharčíková, 2015). Based on the research findings, we can claim there is a constant development of human capital in order to provide the competitiveness of Slovakia and the EU in international markets. The development contributes to the growth of a lifestyle of EU countries' populations, Slovakia included. Recently, there have been several tendencies appearing, such as increasing flexibility of the labour market and ageing of the European population. Regarding these changes, there is a growing necessity to increase the quality and value of human capital. We consider the development of the dual education system, support of the lifelong education and increasing the quality of life to be the best tools and measurements for achieving the goal (Palaščáková, Kol’veková \& Palaščáková, 2018). The number of students, as well as the number of universities, do not reflect the needs of the labour market, nor the possibilities in Slovakia. The excessive number of universities results in a large diffusion of the resources of the state funds to support the higher education in Slovakia. This is the reason why the potential growth of more high-quality universities is financially important and on the other hand, the spectrum of the educational institutions of various quality is funded blindly.

It will be necessary to solve even other serious matters in the future. We can discuss the issues such as the differences between the income assessment of the work of men and women, as well as significant differences within the population lifestyle among particular EU countries. 


\section{Acknowledgment:}

This paper is a part of the project findings; the project is: VEGA 1/0961/16 - Economic Implications and Perspectives of the Participation of the Slovak Republic in the Process of Production Activities Fragmentation within Global Value Chains.

\section{References:}

Armstrong, M. (2007). Řízenílidských zdrojů:nejnovější trendy a postupy, 10. vyd. Praha: Grada, 2007, 789.

Armstrong, M., \& Taylor, S. (2015). Řízení lidských zdrojů: moderní pojetí a postupy, 13. vydání. Překlad Martin Šikýř. Praha: Grada Publishing, 928.

Barro, R. (1996, August). Determinants of Economic Growth: A Cross-Country Empirical Study. Cambridge: National Bureau of Economic Research, Working Paper 5698.

Bassanini, A., \& Scarpetta, S. (2001). The Driving Forces of Economic Growth: Panel Data Evidencefor the OECD Countries. OECD Economic Studies, 33(2), 9-56.

Becker, G.S. (1993). Human capital: a theoretical and empirical analysis, with special reference to education, 3 rd ed. Chicago: The University of Chicago Press.

Bielik, P. (2007). Podnikové hospodárstvo, 1. vyd.. Nitra: SPU.

Blundell, R. et al. (1999): Human capital investment: The returns from education and training to the ndividual, the firm and the economy. Fiscal studies, 20, 1-23.

Danquah, M., \& Amankwah-Amoah, J. (2004). Assessing the relationships between human capital, innovation and technology adoption: Evidence from sub -Saharan Africa. Technological Forecasting and Social Change, Elsevier, 122 (C), 24-33.

Dobeš, M. (2000). Rate of return on investment in human capital. Individual and Society, 3(4).

Dobeš, M. (2017a). L'udský kapitál a výkonnost' ekonomiky. Retrieved from http://www. saske.sk/stredisko/ludsky_kapital.pdf (10.01.2017).

Dobeš, M. (2017b). L’udský kapitál a ekonomika. Retrieved from: http://www. clovekaspolocnost.sk/jquery/pdf.php?gui=ANS75F89LEZR9Q1U15I BKUYXC+ (08.01.2017).

Galor, O., \& Tsiddon, D. (1997, June). Technological Progress, Mobility, and Economic Growth. The American Economic Review, 87(3), 363-382.

Hanushek, E.A. (2012, December). Do better schools lead to more growth? Cognitive skills, economic outcomes, and causation. Journal of Economic Growth, 17(4), 267-321.

Hanushek, E.A., \& Woessmann, L. (2012). The Economic Benefit of Educational Reform in the European Union. CESifo Economic Studies, 58(1), 73-109.

Heckman, J. (1998). What should be our human capital investment policy? Fiscal Studies, 19, 103-119. 
Hudec, O. (2007) Štatistické metódy v ekonomických vedách. Košice: Elfa, 2007.

https://ec.europa.eu/eurostat/statistics-explained/index.php/Employment_statistics/

sk Kačírková, M. (1998.) Regionálne pohlady na nezamestnanost̉ na Slovensku vo vztahu k podnikatel'ským aktivitám a úrovni vzdelania. Ekonomický časopis, 46, 280-292.

Kucharčíková, A. (2015, April 22). Human Capital Management - Aspect of the Human Capital Efficiency in University Education. Procedia - Social and Behavioral Sciences, 177, 48-60.

Lee, J., Ihm, J., \& Ryu, D. (2017, May). Human capital measures and stock return predictability: Macroeconomic versus microeconomic approaches. Finance Research Letters, 21, 53-56.

Lisý, J. (2007). Ekonómia v novej ekonomike. Bratislava: Wolters Kluwer (Iura Edition).

Mazouch, P., \& Fischer, J. (2011). Lidský kapitál: měření, souvislosti, prognózy. Praha: C.H. Beck.

Michael, R. (1975). Education and Consumption: Education, income, and human behavior. New York: McGraw-Hill Education.

Mincer, J. (1958, August). Investment in Human Capital and Personal Income Distribution. Journal of Political Economy, 66 (4), The University of Chicago Press, 281-302.

Mincer, J. (1994). Studies in Human Capital. Columbia: Edward Elgar Publishing.

Onkelinx, J., Manolova, T.S., \& Edelman, L.F. (2016) The human factor: Investments in employee human capital, productivity, and SME internationalization. Journal of International Management, 22(4), 351-364.

Palaščáková, D., Kolveková, G., \& Palaščáková, L. (2018). Integration processes and cooperation of the European Union countries in the scope of education and training policy. 4th International Scientific Conference on European Integration 2018 (ICEI 2018), 17th - 18th May 2018, Ostrava, Czech Republic, 1139-1146.

Pelinescu, E. (2015). The Impact of Human Capital on Economic Growth. Procedia Economics and Finance, 22, 184-190.

Smith, A. (2008). An Inquiry into the Nature and Causes of the Wealth of Nations. Oxford: Oxford University Press.

www.statistics.sk

\section{Lenka Palaščáková}

Doctoral student of the Armed Forces Academy of General Milan Rastislav Štefánik in Liptovský Mikuláš (study programme at the Security and Defense Department), which is the fundamental university and research institution for national, international security and military arts. In her research she focuses on legal aspects of the pursuit of martial sports and arts within self-defense skills of members of the Armed Forces of the Slovak Republic, likewise, on security 
policy and cooperation in this field with other civil and military institutions at home and abroad. As a doctoral student, she has published more than 30 papers in proceedings of scientific conferences and in journals focusing on the study of the relationship between security, sport and justice.

e-mail address: palascakova.lenka@gmail.com

\section{Daniela Palaščáková}

Works at the Faculty of Economics, Technical University of Košice. Her pedagogical and scientific activity concentrates on economic policy, world economy, political science, sociology, business ethics and international economic relations. She has published over 100 papers in proceedings of scientific conferences and in scientific journals. Her interests in the theory and practice of economy and creation of quality management systems in the context of competitors have been deepened by various research projects, where the tasks were focused on the following research areas: economic, ecology and social problems of the region, the environmental protection, start-up entrepreneur's issues, etc. At the international level it is especially the following areas: social policy in the European Union and social economy, new trends in public and social economy, Corporate Social Responsibility in practice. e-mail address: daniela.palascakova@tuke.sk 